\title{
Learning in Community: Small Group Leadership for Educational Change
}

\section{Mary Louise Holly}

Kent State University. Faculty Professional Development Center

Kent, OH 44242 USA

mholly@kent.edu

\section{Resum}

El text s'articula en tres idees: les comunitats d'aprenentatge com a agents de canvi, la investigació en l'acció i la transformació mitjançant la conversa. Totes es troben estretament relacionades i permeten explicar-nos els canvis individuals i col-lectius. Les comunitats d'aprenentatge constitueixen una important força de transformació; se les considera un enclavament per a l'aprenentatge actiu i incubadores de la innovació. A mesura que creixen mitjançant la conversa, desenvolupen un llenguatge i un coneixement col.lectius. D'altra banda, la investigació en l'acció té lloc en comunitats d'aprenentatge. Se les considera una oportunitat de verificar les pròpies creences en la pràctica, així com noves formes de portar la pràctica educativa a la realitat. El text descriu tres grans comunitats d'aprenentatge i mostra de quina manera l'staff universitari té un paper important en el desenvolupament del canvi, mitjançant la recerca en l'acció.

Paraules clau: comunitats d'aprenentatge, agents de canvi, transformació en la conversa, canvi individual i en grup, transformació cultural, recerca en l'acció i universitats.

\begin{abstract}
This article is elaborated around three key ideas: learning communities as agents of change, action research and transformation through conversation. All of them relate very strongly together and help bring about individual and group change. Learning communities are powerful forces of cultural transformation; they are considered an enclave for active learning and therefore an incubator of innovation. As they grow as a group through conversations, they develop both a collective language and knowledge. On the other side, action research can take place in learning communities. It's seen as an opportunity to test one's beliefs in practice and to bring new forms of educational practice into reality. The text describes the three larger statewide learning communities and explains how the university staff takes an important role in bringing about change through action research.
\end{abstract}

Key words: learning communities, agents of change, transformation through conversation, individual and group change, cultural transformation, action research, university.

\section{Resumen}

El texto se articula en tres ideas: las comunidades de aprendizaje como agentes de cambio, la investigación en la acción y la transformación mediante la conversación. Todas ellas se hallan estrechamente relacionadas y permiten explicarnos los cambios individuales y colec- 
tivos. Las comunidades de aprendizaje constituyen una importante fuerza de transformación; se las considera un enclave para el aprendizaje activo y como incubadoras de la innovación. A medida que crecen mediante la conversación, desarrollan un lenguaje y un conocimiento colectivos. Por otra parte, la investigación en la acción tiene lugar en comunidades de aprendizaje. Se las considera como una oportunidad de verificar las propias creencias en la práctica, así como nuevas formas de llevar la práctica educativa a la realidad. El texto describe tres grandes comunidades de aprendizaje y muestra el modo cómo el staff universitario juega un papel importante en el desarrollo del cambio mediante la investigación en la acción.

Palabras clave: comunidades de aprendizaje, agentes de cambio, transformación mediante conversación, cambio individual y en grupo, transformación cultural, investigación en la acción, universidad.

\begin{aligned} & \multicolumn{2}{c}{ Summary } \\ & Learning communities Appendix 1 \\ & as agents of change Appendix 2 \\ & Action research on matters Appendix 3 \\ & of educational consequence Appendix 4 \\ & Transformation by conversation References \\ & In conclusion \end{aligned}

As agents of change, the question is how do we transform our institutions? The simple response is community by community; bird by bird ${ }^{1}$.

The more complex response requires us to address the question: what mechanisms and strategies can we create and sustain to enable us to bring our educational aspirations in line with our practice? How can we create a future where our values and priorities guide practice, where we act on our professional commitment and knowledge in this time of regressive political and economic environments where simpler answers (e.g. standardized curricula, testing, and efficiency) promise a return to «simpler times»?

One response lies in supporting the transformation of the educational imagination and vision of policy makers and evaluators so that they can appreciate the richness of increased capacities and creativity possible when one cultivates learning environments for success. How do we enable such transformation to begin? By inviting policy makers and evaluators into communities of practice (Wenger et al., 2002) where their attention is focused on cultivating rich educational environments for students.

1. In Bird by bird (1994) Anne Lamott tells the story of her ten year old brother, overwhelmed by the daunting task of sitting down the night before an assignment was due to write a report on birds that he had had three months to write, getting counsel from their father: "Bird by bird Buddy. Just take it bird by bird». 
The learning community as we will refer to it here has been known, in one guise or another, since the time of John Dewey. Dewey, and Alexander Meiklejohn, developed the concept of student learning communities for higher education in the 1920's and 1930's (Cox, 2003). The purpose of the learning community for the educational researcher has usually been to foster advancement of scholarship and practice in educational settings. It is argued here that this same structure offers a framework for cultural transformation in a new world where the politics of change carry at least as much weight as does the quality of teaching, learning, and scholarship. To elaborate past successes and the potential for learning communities to foster change in the future, we will develop our discussion around three key ideas: learning communities as agents of change, action research on matters of educational consequence, and transformation through conversation.

\section{Learning communities as agents of change}

For a change agent to be successful, at least four things are needed: 1) envisioned alternatives; 2) compelling reasons to grow and change; 3) actions that enables change, and 4) structures for sustaining changes until they become accepted practice. The learning community offers a form of social interaction with structural elements that enable it to be both catalytic and sustaining of cultural transformation. Unlike committees, task forces, and other team approaches, the learning community is rarely structured to include or exclude members; it is not designed to broker solutions to meet everyone's needs, nor do learning communities exist to meet external standards. (See Appendix 1 for characteristics of committees and communities.) According to Milton Cox (2003), a learning community is typically comprised of a small group of individuals who come together around a common interest and topic (e.g. science education; learning and teaching on-line, service learning), or a cohort (e.g. freshmen students; untenured faculty). The main objective of community is active and consequential learning. As we will see later, small groups of individuals networking with others can soon become a powerful force for change.

The learning community is an enclave for innovative thinking, its collegial environment fosters new ideas that lead to change. As we move from a less complex paradigm of change to a more complex paradigm of transformation where change is viewed as part of larger processes and systems, individuals who fit well into the earlier paradigm will find it difficult to adjust to the present one (See Appendix 2 on Educational Change). As one educational leader (Kopp, 2003) recently put it, "Learning communities are for rainmakers, for people who think outside the box. These rainmakers are not usually long-time residents at an institution because they think differently, but they are just what we need for creative change».

According to Maxine Greene, when we think of community, we need to emphasize the process: making, creating, weaving. "Community cannot be 
produced, simply through rational formulation nor through edict. Like freedom, it has to be achieved by persons offered the space in which to discover what they recognize together and appreciate in common: they have to find ways to make inter-subjective sense." She continues, «it ought to be a space infused by the kind of imaginative awareness that enables those involved to imagine alternative possibilities for their own becoming and their groups' becoming" (1995, p. 39). For Greene, "Community is not a question of which social contracts are the most reasonable for individuals to enter. It is a question of what might contribute to the pursuit of shared goods: what ways of being together, of attaining mutuality, of reaching toward some common world».

In recent years we have learned much about learning, about how people learn (Bransford et al., 1999), how the brain functions including the relationships of emotion and feelings to learning (Le Doux, 1996), how we can ascertain what students (and colleagues) know and how they know it (Kegan, 1982, 1994; Magolda, 1992, 1999; Levine, 2002; Pellegrino et al., 2000), the key role of peers and colleagues in learning (Harris, 1998), and the biological and neurological mechanisms and processes of learning and growth of the self (Zull, 2002; Carter, 1999; Kegan, 1982; Le Doux, 2001). A few of the more critical points related to learning and change include:

- learning is a physical process; learning physically changes the brain at the neuronal level;

- once something is learned, it stays as a connection; new learning cannot make it go away or replace it - but it can make other connections that can become more dominant;

- learning has an emotional component; the wedding of emotional and cognitive functions makes possible a shift from reaction to action and with it, a veritable "explosion of cognition» (LeDoux, 1996); "Knowing is a feeling» (Zull, 2002);

- people learn from one another; peer learning and influence is much stronger than most of us know; we can often better understand a concept when taught by someone closer to our level of understanding than from someone who is far more knowledgeable and who has "forgotten» what it means to be a novice;

- there are several phases of learning which include trying something out; Kolb's learning cycle (1984), for example, suggests that deep learning (comprehension) comes through a cycle of experience, reflection, abstraction, and active testing which is born out in biological studies of brain functioning (Zull, 2002);

- you can only learn from where you are (or effectively teach from where the student is): prior learning is the single most important factor in success at learning; connections can only be made from the connections that already exist; the mind is not a «blank slate».

With these points in mind, it is not hard to understand why a community can be such a powerful environment for learning. There are two interactive 
levels of connection working here: individuals making connections at the level of internal neuronal networks, and individuals making connections with one another through conversations. The community aspect denotes the value of each member, and a safe environment where trust and collegiality make possible opportunities for trying out new ideas, risking failure, learning from what doesn't work as well as what does, and appreciation of alternative perspectives. In the words of Hannah Arendt (1958), "If action has an aim, it is to enlarge the space in which human beings can relate to each other as unique individuals in a situation, such an aim is not the intention to produce an outcome or result, but a value built into the process of action itself». The quality of conversations that can take place within the community can lead to growth of significant social value as individual ideas become stepping stones to higher places and more complex thinking, and not infrequently, simple solutions to significant problems that work. Rather than a delineation of competing positions, there is usually general agreement on the direction of change.

As the learning community conversation grows in history and richness and members generate new ideas, the group develops shared language and knowledge. For shared values and language to accomplish change, both must move outside of the originating group of individuals and continue to live and grow in other networks of conversation and action. Learning communities are part of larger communities within which they function and through which the fruits of their actions become manifest. We will soon discuss an example of a learning community, the Teaching Scholars at Kent State University, who share their experiences within their departments and colleges and within the larger communities of the university, as well as with conference participants at region$\mathrm{al}$ and national levels. Publications written by community members are another way that members communicate in larger communities.

The two key concepts, learning and community make possible a powerful structure for shaping and bringing about individual and group change. Learning is the aim of each member and of the community; and each member is a unique contributor to the processes of learning that the community undertakes. This learning is inextricably intertwined with social change; the action part of learning, yet it is not merely change as in «more, better, faster» but as part of a larger transformational process that is different from the past; the learning is generative. This learning leads to further growth and experience, and into places not predicted when the journey began.

There seem to be several key elements in the structure of learning communities (See Appendix 3) that work well to support small group leadership for change. For example, a learning community offers both security and challenge. They provide space for interdisciplinary and inter-role conversation, where community members (who can be faculty, students, staff, administrators, and others) are valued for their unique perspectives and ideas can be entertained and tried out. The social nature of the learning community provides a strong impetus for the kinds of conversation that can come to fruition in different ways and places. 
Although each learning community is unique, there are other common elements including communication, and as Milt Cox, long-time proponent of learning Communities at Miami University, calls them: social amenities (food, drink, resource materials, retreats, receptions) and common experiences such as bi-weekly or monthly seminars and workshops, sessions where guests are invited to discuss specific topics and members share their expertise, including progress with individual and group projects.

In the Teaching Scholars for Early Career Faculty Learning Community, for example, eleven pre-tenure faculty members from various disciplines and campuses meet bi-weekly for one and a half to two hour sessions that include: discussion of individual projects and of a group project that evolved on fostering critical thinking in the various disciplines, planning a university campus conversations session that would kick off the annual fall conference "Celebrating College Teaching» and involve the university community (students, faculty, administrators, staff) in conversations on teaching and learning, sessions with faculty mentors and student associates (a lunch seminar in the first case, an afternoon tea in the second), and planning for community participation in a national conference on college teaching. A session after the conference involved debriefing and sharing materials and experiences. Winding up the year in the spring, the Teaching Scholars participate in a reception where each learning community shares highlights of their experiences with interested people from the larger university community as well as new members who will create new learning communities in the summer.

With shared interest, commitment, and time, community members' actions, individually and collectively, can bring about educational change, The "content» of their vision and the methods by which its elements come to life are the province of action research.

\section{Action research on matters of educational consequence}

According to Wilfred Carr (2003), action research is not a thing, or a method, it's an educational aspiration. He relates action research to his belief that education should be based on what he distinguishes as a good society. Action research is both a call to action and the action itself. The action that it fosters is educational (leading to further capacity for learning in socially significant ways) in at least two ways: something is changed that enables others to grow, and the researcher herself or himself is changed. In the language of learning, there are new neural connections, and thus new avenues for further action; the action produces growth of the person(s) acting, for as Hannah Arendt suggests, "the self only exists in action".

A call to social action, to improve education by theorizing and testing one's ideas in practice, is what brings the people together in the first place. Action research is a process for systematically, self-critically, inquiring into one's practice, for documenting the process as well as the results, and for portraying the results for public conversation and critique, analyses, syntheses, and further 
action. The reflective processes (continuous cycles of act-observe \& portrayreflect which are akin to Kolb's learning cycle of experience, reflection, abstraction and active testing) of action research that enable documentation and learning from experience are foundational for making educational policy, program and curriculum development, assessment and evaluation. The portrayal phase of action research makes dialog and understanding possible; it enriches the conversation, brings monolog into dialog; makes possible the evolving language of educational research on practice - what some might call an evolving knowledge base for educational action.

The social aims and actions that call a learning community into being, whether trying to better understand the lives of college freshmen in order to improve the educational opportunities for them, or enabling beginning college professors to study and explore their teaching and students' learning as they form a foundation for their collective careers of service, are matters of high consequence. When we step back from the fast clicking keys of postmodern life, these are matters worth bracketing, worthy of our commitment, resources, and energy. To give a local and a statewide example, Kent State University's seven Learning Communities, including the Teaching Scholars, are developed around several areas key to the university's mission and strategic goals, the first goal of which is Cultivating learning centered environments for success. (See Appendix 4 for a brief description of the learning communities.)

These interdisciplinary learning communities involve members at different campuses, kinds and levels of responsibilities, students, faculty, staff, and administrators, and are linked with other networks of learning communities: one supported at the national level by the Fund for the Improvement of Post Secondary Education (FIPSE), two supported at the state level by the Ohio Learning Network (OLN), and the Ohio Board of Regents (OBOR), and at the institutional level through the Faculty Professional Development Center, the Office of the Provost, and other offices. Three communities are part of a statewide consortium of thirty-one learning communities, supported by the Ohio Learning Network. All seven are linked to five other institutions that are part of a three-year FIPSE grant under the leadership of Milton Cox of Miami University, to support organizational transformation on behalf of student learning.

\section{Transformation by conversation}

Rainmakers are on a mission. As agents of change, educational researchers can best be positioned where the action is - and this isn't usually found in committee meetings. While committees are useful for many things, they are rarely incubators of innovation, or the kinds of spaces where colleagues can shape ideas, challenge themselves and each other, and remain lithe and spirited enough to follow their inquiry where it leads them. (See Appendix 1 for elements of committees and communities.) In today's national and international contexts, competition often means 'more, better, and faster' in a world of increasing vol- 
ume, complexity, capacity, and an unprecedented and increasing rate of change ${ }^{2}$, establishing structures for community and the kinds of dialog that fuel creative action may be going against the grain. A faculty member, these days, can «sit» on "more» committees and engage in "less» thoughtful conversation with colleagues.

With less time for specific activities (more meetings, less preparation time) and potentially greater impact (more information available to more people and at greater speed), learning from experience, which is the purpose of action research, becomes even more important than it might be in «slower» times. The kind of thoughtful practice necessary to living one's aspirations takes time: "thoughtfulness is enacted through public dialogue. We learn to be thoughtful - to be ourselves - through interaction, transaction, and engagement (Nixon, 2003). Theorising takes time and «involves the difficult art of arguing beyond the dead-end of disagreement to albeit provisional and sometimes risky modes of collaborative endeavor» (Nixon, 2003).

As John Elliott continues to remind us, teaching is a moral craft; it takes moral conversations on a foundation of human literacy to keep this complex, moral craft a generative process of educational experience. It will not take more money, more people, or faster communications, although each of these can help. The kinds of transformation that will make a difference in educational practice will come about as educational researchers become agents of change through the processes of community development and thoughtful action. With the strong leadership and stewardship of John Elliott, the Collaborative Action Research Network (CARN) which he founded, is an excellent example of a network of continuing conversations that span time, roles, geography, systems of government, disciplines and careers (education, nursing, juris prudence, to name a few), and has been a source of continued engagement of educational researchers world-wide, including England, Scotland, Wales, Spain, Austria, Australia, the United States of America, and Canada. Several elements of the large community help to keep the conversation alive: communication through the internet and electronic mail and listservs, publications including a journal and many occasional papers, a steering committee and group leadership.

The structures for bringing conversation to the level of engagement needed for cultural transformation (beginning «bird by bird») are to be found in educational action research, as CARN illustrates. The language through which educational researchers share their inquiry, case studies and portraits of practice, for example, where most people who read or hear of the inquiry are able to understand it, the stories and narratives, if you will, make possible new and continuing conversations. As people become part of the conversations generated by and through learning communities, social action is propagated to new

2. Between the years 1999 and 2002 the total number of publications that had taken place in the history of publication before 1999, doubled; the next doubling only took one and a half years. 
environments, new connections are made and in the process of making them - are transformed into foundations for further learning.

Learning community research becomes the foundation for each of the members, as well as the group, to bring new forms of educational practice into existence, and, as in the cycle of action research, leads to the next phase of engagement and action. Keeping the conversation in existence is the key to educational transformation. To do this, agents of change need a focus (aspirations; purpose), membership, methods of inquiry (action research), and the media (forums for sharing and propagating the conversations) to keep it in existence.

We will have succeeded when the ideas that sprouted in the learning community become part of the lexicon and strategic plans and conversations of those in leadership and policy-making positions. The sources for ideas that lead to educational change may be long forgotten, yet the community model that enabled their development is small group leadership. This process of supporting collegial conversations and collaborations that leads to group leadership runs counter to the more common competitive «star model» of individual leadership and reward. In the former, if there is a «star», it is the community.

What does successful small group leadership lead to? In mapping the consequences in terms of success, there are many, not the least of which can be seen over time in the educational imaginations and vision of leaders and policy makers. A high level administrator, for example a college president, provost, or dean, supports (levels of support vary from moral to financial to representation on or actual membership in communities) the development of a learning community for beginning faculty and later assumes a state or national level position where he or she continues conversations that started in the learning community. A provost becomes chair of a state agency where he is a spokesperson and supporter of state initiatives akin to those he supported and learned from within his own institution. Another example is where members of the learning community became leaders in groups such as Faculty Senate, a University Teaching Council, and a Faculty Professional Development Center Council. At Miami University in Ohio, where faculty learning communities have been inexistence for a quarter of a century, a high proportion of faculty leaders, department chairs, and other administrators are former community members ( $1 / 3$ of the university faculty members have been part of learning communities).

It is not difficult to see how conversation within a 10 person community spreads, and that when you have several communities, through networking, the connections continue to grow until there are hundreds of agents for educational change.

\section{Bird by bird, community by community}

While it may not be difficult to see the changes in members of the Teaching Scholars as professors from very different fields as they focus on the processes 
of teaching and learning within their disciplines and develop meaningful; relationships with one another across disciplines - observing in one another's classes, reading common literature, testing out their ideas in practice and sharing their action research experiences - it may not be as obvious how their experiences change the conversations beyond the immediate community. We will take a brief look at a few examples and it will become apparent that bird by bird can be a subtly powerful method for change, each bird an agent.

\section{Teaching Scholars for Early Career Faculty Learning Community}

In chemistry, as in many of the physical sciences, the department regularly has research colloquia where visiting scholars as well as department members share their research with other science colleagues and graduate students. A member of the Teaching Scholars decided that he would present his research in a colloquia, as expected, but that he would also present his scholarship of teaching on cooperative learning and using technology to make the subject matter more available to all students, not only in one course, but to build programmatic bridges with others. What were a few of the results of bringing teaching into the public realm of research? With focused attention and an audience the scholarship of teaching and learning was given credibility; the language of educational research and the imaginative curriculum development where active and cooperative learning in a large traditionally lecture class format became part of the way chemistry can be learned (especially by non-chemistry majors) was introduced into the professional conversation of scientists in a way that was natural and meaningful. People who may never have entertained different ways of teaching and taking into account student perspectives were, through the personal experiences of the faculty member, brought into a new avenue for conversation and educational action. If even one colleague followed their new curiosity into their own teaching, her students would be benefactors. In sharing his story with new community members at a reception, and responding to questions on "how can I learn more...?» twelve new teaching scholars took the chemistry professor's suggestion of participating in a workshop on the topic of active and cooperative learning. One year later, each of these faculty members were using their imaginations in their disciplines (from Nursing to Art History, Geography, Theatre, Political Science, Library Science, Architecture, Secondary School Science, and English) creatively integrating more active and engaging learning in their classes, and sharing their experiences, not only with one another, but with their disciplinary colleagues.

\section{Information Literacy Faculty Learning Community}

This community is comprised of teams of faculty members from disciplines with librarians. Each team is working on a project to help undergraduate students within specific disciplines to develop their capacities for making judgments on finding credible information, interpreting it, and using it in meaningful ways. One project, for example, entails the work of a senior faculty member in English and a Librarian in this discipline in developing modules that will be integrated into core freshmen English courses, and thus benefit students in all dis- 
ciplines. Another team is comprised of several faculty members in Nursing who work with a Librarian in this area to develop case studies and records to aid information (human and technological) literacy specific to nursing. A team on History at a Regional Campus is developing modules where students get out into the community to learn oral history with local residents. Each of these projects and others (middle school curricula, science education, speech communication) have electronic components and so, as the community members develop their projects, they also develop their expertise and learn from one another, not only how to work together, but how to navigate the information worlds themselves, which they then share with colleagues and students. Another level of consequence is reached when the English team takes their work back to colleagues in the department.

Each learning community is part of several networks that go beyond their units, campuses, and the university. We will conclude these examples with three larger networks in which the communities referred to in this text are linked. One begins to see a web of communication and action. It is our purpose here only to illustrate the complexity of conversation networks that can be powerful agents for change, that can engage the imaginations and generative thinking of people at all levels of educational networks. (More information is available by visiting the URLs provided in the reference section of this paper.)

\section{The Ohio Board of Regents}

The Ohio Board of Regents (OBOR) funded Ohio Teaching Enhancement Program began in 2000 with eight institutions of higher education in Ohio. Based on a Lilly Foundation funded and highly successful Miami University Faculty Learning Communities Program of over twenty years, it's leader, Mathematics professor Milton Cox, designed and led this project with the intention of «Investing in the Future: Enhancing Undergraduate Education in Ohio: Improving Efficiency through Statewide Collaboration». The Teaching Scholars began as part of this network of institutions of higher education in Ohio. Ten institutions have now been part of this program. From this beginning, five institutions joined together for a three-year Fund for the Improvement of Post Secondary Education (FIPSE) funded project (see below). The Ohio Board of Regents also funded another grant that supports learning communities and is built on the success of the Obio Teaching Enhancement Program. English professor Dan Madigan, Center Director of the Teaching, Learning, and Technology Center at Bowling Green State University and a member of the OTEP project, brought together librarians and faculty professional development center directors at BGSU and Kent State University to collaborate on a grant proposal to enhance information literacy at these institutions. The funded proposal included a format for presenting workshops for faculty at each institution, overseeing internal grants for the development of modules in disciplines, and presenting workshops at the state level and overseeing a grant program based on the model developed at BGSU 
and KSU. The extended program develops learning communities at seven institutions which develop learning modules available to all educators through the website.

\section{The Fund for the Improvement of Secondary Education}

This three-year project entitled: Developing Faculty Learning Communities to Transform Campus Culture for Learning, extended the network discussed above under the Ohio Board of Regents beyond Ohio and provided a framework and community for directors who would oversee the development of at least six learning communities at each of the six institutions. (See the reference list for a URL that links to many learning communities.)

\section{The Ohio Learning Network}

With a bold statewide project designed to build on these efforts and targeted to enhance learning with the use of educational technology, the Ohio Learning Network issued a call for proposals that ultimately funded 31 learning communities in Ohio for the 2002-2003 year, and from this, funded 13 impact grants, with a new call for new learning communities for the 20042005 year. There were several ways that this initiative stepped outside traditional boundaries for a state agency, including: an overt foundation of pedagogy and principles of learning and development; funding summer 'planning grants' that enabled faculty members and others to plan their communities and develop their proposals; two statewide sessions and one regional session to bring learning community members together, one to kick off the initiative in October, five regional Learning Institutes that brought several learning communities each together in January, and a June Gathering to share the fruits of community projects; and action research approach where learning from experience and sharing that experiences with others was the modus operandi, a format for reporting that focused as much on the processes of developing the community as it did on the specified products and modules of the community, and, shared resources available to all on the OLN website under «Athenaeum».

\section{In conclusion}

Outside of academia, there is already an extensive conversation about the importance, needs and characteristics of education that is taking place in the arena of politics and social commentary. In this arena consensus is developed and decisions are made on the nature of education, its funding, and its future. Our thesis here is that arguing in that arena is misguided. The potential for change is intrinsically limited when the discussion takes place in the context of values and language that have developed around what's wrong with our educational systems. Or, as Michael Lee (2004) put it: «You cannot use a 
conversation that is grounded in deficiency to create plenty». The alternative to argument is recreating the conversation and those who participate.

To end as we began, with the educational imagination and vision that is possible, not with standards that are tethered to the past and to "fixing what is wrong» to meet yesterday's goals, but with commitment to what Maxine Greene calls communities of regard. "If we can link imagination to our sense of possibility and our ability to respond to other human beings, can we link it to the making of community as well?» To "community that is always in the making?» (1995, p. 39).

\section{Appendix 1}

Differences between committees and communities

\section{Committee}

Purpose: work, accomplishment

There is usually a known end

There is a leader and product

Work, task, create product oriented

Organized before and follow steps

Sit on a committee

Image for success: work horses

Product is paramount

Emphasize cognition; limit emotion Apply theory to task

Lasts until task is completed

Boundaries clear

\section{Community}

Purpose is learning through action

The end is not delimited

There is a facilitator; emphasis on process

Learning, professional development, growth, action to create change oriented

Develop organization with community

Serve in a community

Image for success: rainmakers

Curiosity and personal — group value priority. Process is integral part of product

Whole person; emotional brain an asset

Theorize; create

Evolve and end naturally when learning yields to new phases

Boundaries fuzzy

While committees can function as communities, their purpose is rarely to "create, expand, and exchange knowledge, and to develop individual capabilities» (Wenger et al., 2002, p. 42).

Consult Wenger et al. (2002, p. 42) for a chart describing the differences between and among Communities of Practice (what we have called learning communities in this paper), Formal Departments, Operational Teams, Project Teams, Communities of Interest, and Informal Networks. 


\section{Appendix 2}

Future orientations to educational change in social settings

From

Focus on problem: Fix it

Standards and accountability

Hierarchical organization

Objectives oriented

Change: more better faster

In the box: following the rules, standards

Setting $\&$ achieving behavioral objectives

\section{Measurement}

Summative evaluation

Follow the plan

Investment ends when committee ends

Application of theory

External Researchers

Contain emotions, bracket feelings

Monitored discussion

Monolog

Individual practitioners

Focus on Quantity and end result

Policy makers create objectives

Meetings focused on end result
To

focus on future

values and priorities; personal and group commitment and responsibility

democratic organization

process oriented

transformation: different

out of the box: action and innovation

generating expressive outcomes;

imaginative action cultivating diversity; quality

qualitative and quantitative assessment

formative and summative evaluation

documenting the journey

investment in the impact on the future is high

theorizing: Action Research

practitioner research

emotions and feelings help to guide meaningful action

generative conversations

dialogue; multiple perspectives and views

critical friends and colleagues

focus on quality and process

practitioners create aims and goals

meetings flexible, evolving agenda 


\section{Appendix 3}

\section{Structural elements of learning communities}

- Focus: matters of social significance with commitment strong enough to sustain.

- Leadership: leaders (often co-leaders) facilitate community's agenda for learning.

- Mode of learning: action and learning from experience; educational action research.

- Individual and or group projects maintain ownership and momentum.

- Generate action: creates something new; cycles of reflective practice.

- Meetings: regular seminars, workshops, forums for members and others.

- Inquiry: by people who don't typically research their practice: community member practitioners.

- Membership: cross disciplinary, cross institutional, levels of education, and diversity of roles within and outside an institution; Attention to inclusion (and support) in call for participation; inclusive.

- Forums: linking Learning Communities and outreach (groups within an institution and outside it including geographically diverse groups; conferences).

- Outcomes: often cannot be predicted beforehand; project and person in action change.

- Documentation: Attention to documentation of processes of community development and action are as important as the consequences.

- Propagation: often primary, essential for creating change; sharing results in different venues; Attention to methods of sharing results of community action.

- Outlets: a focus on how results are told or shown; stories (narratives), case studies are often created.

- Consciousness: «Thoughtfulness is ordinary» (Nixon, 2003); in learning community it becomes a conscious process.

- Networks of conversations: Develop networks of conversation and reflective action; create structures (as above) to sustain arriving at something; real impact if larger community of interest is discussing the idea. 


\section{Appendix 4}

\section{Seven learning communities at Kent State University}

- Teaching Scholars for Early Career Faculty is focused on the scholarship of teaching and learning. Members engage in action research on their individual teaching practice as well developing a group project on supporting student's critical thinking within the disciplines.

- Collaborative Technologies explores methods and tools for collaboration and community building with classes and across institutions and roles; they begin with exploring methods and tools on a collegial level and then take these into their own and other's classrooms for student and teacher use and perceptions.

- Faculty and Future Faculty is comprised of faculty and graduate students who focus on teaching and learning in courses designed to help graduate students learn to teach at the college level. They develop learning modules (how to develop a syllabus; assessment and evaluation; principles of human development and learning, for example) that can be used across disciplines for those teaching and taking courses on college teaching, and are finding that both new faculty and faculty who have not had educational experience with college teaching find the modules worthwhile.

- Great Starts: Connecting the Mosaic is a new professional learning community where staff, administrators, and faculty from various disciplines and offices (Undergraduate Studies, Resident Services, Campus Life, coordinators and faculty members teaching in student learning communities) explore freshmen life and learning, each from their unique perspective and role within the students' experiences. The community is a place for sharing their perspectives, pooling individual interviews and conversations with freshmen students, and developing understandings and actions.

- Information Literacy is comprised of five teams of disciplinary faculty members and librarians each of which is developing tools and modules within courses to enable students to develop their abilities to acquire and to discern worthwhile and credible information; members deepen their own learning in information, technological, and human literacy as they work together to create and test out materials in beginning level courses and curricula.

- On-Line Learning and Teaching is comprised of members who have a range of experience levels in teaching and in using educational technology, from those curious and exploring new terrain to highly experienced people who want to push the edges of their known worlds with individual projects in a community environment.

- Learning and Teaching in Large Classes is a new community comprised of faculty members who teach classes with enrollments of from 60-400 students. How does one engage students actively with meaningful work in large classes? Members come with different levels of experience and projects. 


\section{References}

Arendt, H. (1958). The Human Condition. Chicago: University of Chicago Press. Bransford, J.; Brown, A.; Cocking, R. (eds.) (2000). How People Learn: Brain, Mind, Experience, and School. National Research Council. Washington DC: National Academy Press.

CARR, W. (2003). Remarks made during the closing session of the Simposi Internacional: "The educational researcher as an agent of educational change/L'investigador en educació com a agent de canvi educatiu». Universitat Autònoma de Barcelona.

Carter, R. (1999). Mapping The Mind. London: University of California Press.

Cox, M. (2003). Sourcebook 2003: Designing, Implementing, and Leading Faculty Learning Communities: Enhancing the Teaching and Learning Culture on Your Campus. Oxford, Ohio: Miami University.

Elliott, J. (1991). Action Research For Educational Change. Milton Keynes: Open University Press.

Greene, M. (1995). Releasing the Imagination. San Francisco: Jossey-Bass.

Kegan, R. (1982). The Evolving Self. Cambridge, Mass.: Harvard University Press.

- (1994). In Over Our Heads: The Mental Demands of Modern Life. Cambridge, Mass.: Harvard University Press.

KolB, D. (1984). Experiential Learning: Experience as the Source of Learning and Development. Englewood Cliffs, NJ: Prentice Hall.

KopP, S. (2003). Remarks made during the December OLN Governing Board meeting.

LAmOTT, A. (1994). Bird by Bird. New York: Anchor Books.

LeDoux, J. (2002). The Synaptic Self: How Our Brains Become Who We Are. New York: Penguin Putnam Inc.

- (1996). The Emotional Brain: The Mysterious Underpinnings of Emotional Life. New York: Simon \& Schuster.

LeE, M. (2004). Personal Communication. Kent, OH: Kent State University.

Levine, M. (2002). A Mind At A Time. New York: Simon \& Schuster.

Magolda, M.B. (1999). Creating Contexts for Learning and Self-Authorship: Constructive-Developmental Pedagogy. Nashville: Vanderbilt University Press.

NixON, J. (2003). "What is Theory?». Paper presented at the Simposi Internacional: "The educational researcher as an agent of educational change/Linvestigador en educació com a agent de canvi educatiu». Universitat Autònoma de Barcelona.

Pellegrino, J.; Chudowsky, N.; Glaser, R. (eds.) (2001). Knowing what Students Know: The Science and Design of Educational Assessment. Washington DC: National Academy Press.

Wenger, E.; MCDermott, R.; Snyder, W. (2002). Cultivating Communities of Practice. Boston: Harvard Business School.

Zull, J. (2002). The Art of Changing the Brain. Sterling, VA: Stylus Press.

\section{Websites}

Collaborative Action Research Network:

http://www.did.stu.mmu.ac.uk/carn/

Ohio Learning Network:

http://oln.org/ 
Miami University FIPSE Learning Communities Initiative: http://www.units.muohio.edu/fld

OBOR - BGSU/KSU Information Literacy Grants:

http://www.bgsu.edu/colleges/library/infosrv/lue/oborinst_infolit/

Kent State University Faculty Professional Development Center Learning Communities:

http://fp.dl.kent.edulfpdc/teaching/lc.html 